Tips om medisinsk litteratur, andre bøker, filmer og elektroniske medier som bør anmeldes, sendes tidsskriftet@legeforeningen.no

\section{Ujevn trygdemedisinsk veiledning}

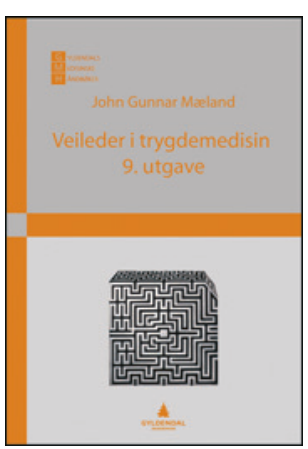

John Gunnar Mæland Veileder i trygdemedisin

9. utg. 150 s, tab, ill. Oslo: Gyldendal

Akademisk, 2016. Pris NOK 329

ISBN 978-82-05-48456-6

John Gunnar Mælands trygdemedisinske veileder kom første gang ut i 2003. Nå er den blitt ajourført i en 9. utgave. Den er beregnet på studenter, praktiserende leger og andre behandlere. Hensikten er å gi en samlet oversikt over trygdeytelser, tilhørende faglige oppgaver og dessuten behandlerens rolle og ansvar i den trygdemedisinske virksomheten. Særlig vektlegges sakkyndighetsrollen og krav til gode legeerklæringer.

Boken gir en oversikt over folketrygdloven, og Nav, HELFO og de sosiale tjenestene som forvaltes av Nav beskrives. Forsikring omtales også. Presentasjonen av folketrygdlovens mangfold av aktuelle ytelser er heldekkende. Ved hjelp av stikkordregisteret er det enkelt å slå opp. Det er råd om grensedragning mellom sykdom og en rekke andre forhold, som sorgreaksjoner og konflikter på arbeidsplassen. Alternativer til full sykmelding beskrives. De aktuelle skjemaene blir forklart, likeså begrepene «funksjonsevne» og «arbeidsevne». Navs rutiner for oppfølging av sykmeldte beskrives. Det er også en grei oversikt over bestemmelsene om dekning av utgifter til helsetjenester, administrert av HELFO. Dagpenger, avtalefestet pensjon og pensjonsberegning omtales også.

Mæland tar opp etiske vansker med å kombinere behandler- og sakkyndighetsrollen. Men jeg synes ikke bokens etiske veiledning lenger er tilfredsstillende. Et godt utgangspunkt for revisjon er den nye innledende $\S 2$ i Etiske regler for leger fra 2014. Her står det: «Legen har ulike roller som behandler, sakkyndig og forvalter av velferdsgoder.» Oppgaven med å kombinere rollene gjelder altså langt utover trygdemedisinen. I alle sine roller bør legen praktisere med empati og etisk innsikt. I veilederen klargjøres det ikke at det trygdemedisinske arbeidet, med sine juridiske føringer, foregår innen det samme etiske rammeverk som medisinsk arbeid for øvrig. Den kunne videre gitt råd om hvordan det trygdemedisinske samarbeidet mellom behandler og pasient bør skje rent praktisk. Innen vårt Nav-system er det naturlig også å drøfte kort faglig og etisk den behandleroppgaven som består i å hjelpe til med å bedre pasientens arbeidsevne. Den interessante Forskrift om krav til helsepersonells attester, erklceringer o.l. fra 2009 burde også vært kommentert.

Veilederen er ujevn. Den veileder på en utmerket måte alle helsetjenestens behandlere om folketrygdlovens mangfoldige ytelser. Den etiske veiledningen trenger å bli revidert i 10. utgave.

Hans Magnus Solli

Seniorforsker, Sykehuset i Vestfold

\section{Imponerende veileder i endokrinologi}

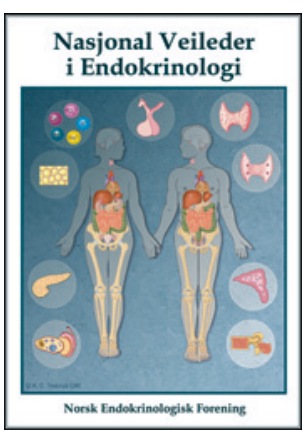

Anders Palmstrøm Jørgensen, Kiarash Tazmini, red. Nasjonal veileder i endokrinologi

163 s, tab, ill. Oslo: Norsk endokrinologisk forening, 2015. Pris: Gratis for medlemmer ISBN 978-82-690118-0-7 (PDF)

Målgruppen til denne utgivelsen er norske endokrinologer, leger under utdanning $i$ endokrinologi og andre leger som behandler pasienter med endokrine sykdommer - et vel ambisiøst mål når man ser på oppsett og detaljeringsnivå. Likevel, jeg synes forfatterne har vært dyktige til å få frem det vesentlige, i et bra, klart språk.

Kapitlet om endokrinologiske tester er det nyttigste, med konkret fremgangsmåte på de ulike testene. Det vil være bra om dette erstattet prosedyrebøkene på sykehusene, slik at det virkelig ble en nasjonal veileder. Det lille som står om laboratorieendokrinologi er for snaut. Når man ser hvor ofte enkeltverdier for hormoner tillegges altfor stor verdi, burde dette kapitlet være mer utfyllende.

Medisinsk genetikk og endokrinologi forklarer de ulike genetiske testenes plass i diagnostikken. For meg, som i likhet med mange andre kliniske endokrinologer ikke har arbeidet med laboratoriegenetikk, var mulighetene og begrensningene ved de enkelte testene viktig kunnskap. Særlig setningen «Laboratoriene skal i prinsippet bare rapportere patogene mutasjoner og eventuelle varianter av ukjent betydning» er tankevekkende - det viser at vi står overfor betydelige tolkningsproblemer når vi kan undersøke «alle» gener.

Formålet med veilederen er å gjøre den kliniske hverdagen lettere. Jeg er i tvil om den gjør det. Den foreligger bare som PDF-fil og er ikke søkbar. Dette er gammeldags. Redaksjonen er åpenbart klar over det og ønsker seg en mobilapplikasjon.

Forfatterne vil gjerne nå allmennlegene. Det er relativt greit å finne ut av en pasient når man vet hva hun feiler. Utfordringen er å finne riktig diagnose, og der fortjener alle leger et oppdatert differensialdiagnostisk dataverktøy som omfatter endokrine sykdommer. Dette finnes andre steder i verden, men er lite brukt i Norge.

Til slutt en sammenligning: Det er opplagt at Helsedirektoratets resultat for diabetes er blitt vesentlig dårligere enn denne veilederen i endokrinologi, på tross av helt andre kostnader og en «grundig» prosess. Det er smertefullt å innrømme, da jeg har vært med på å lage retningslinjene for diabetes! Forklaringen er enkel: Helsedirektoratet har ikke satt brukerne, dvs. legene som skal bruke retningslinjene, i sentrum. Prosessen har vært et eksempel på en «top-down process» hvor Helsedirektoratet har lagt inn premisser fra starten som har hindret retningslinjene i å bli så praktisk anvendelige som mulig. Dette i motsetning til den foreliggende veileder i endokrinologi, som er en «bottom-up process», hvor de som skal bruke veilederen har hatt frie hender til å utforme den.

Gratulerer!

Kristian F. Hanssen

Professor emeritus, Avdeling for endokrinologi, sykelig overvekt og forebyggende medisin

Medisinsk klinikk

Oslo universitetssykehus 